\title{
Reputation, Concessions, and Territorial Civil War:
}

\author{
Do Ethnic Dominoes Fall, or Don't They?*
}

\author{
Nils-Christian Bormann ${ }^{1}$ and Burcu Savun ${ }^{2}$ \\ ${ }^{1}$ Department of Politics, University of Exeter, United Kingdom \& \\ Department of Economics, University of Witten/Herdecke, Germany. \\ Email: n.bormann@exeter.ac.uk \\ ${ }^{2}$ Department of Political Science, University of Pittsburgh, United States
}

Word Count: 9,999

${ }^{*}$ We thank Kyle Beardsley, Alexander Dukalskis, Jesse Hammond, Jude Hays, Philipp Hunziker, Desirée Nilsson, Julian Wucherpfennig, seminar participants at the University of California, Davis and University College Dublin as well as the editor, Kathleen Cunningham and two anonymous reviewers for helpful comments. Previous versions of this article were also presented at the 2012 Annual Meeting of the Peace Science Society in Savannah, GA, and the "Political Contention and New Dimensions of Diffusion" workshop at the University of Exeter in June 2016. Nils-Christian Bormann gratefully acknowledges support from the Swiss National Science Foundation (Fellowship-No. PBEZP1-137308). The online appendix and the replication archive are available at http://www.prio.no/jpr/datasets. All analyses were conducted using $\mathrm{R}$ version 3.4.3. 


\begin{abstract}
Barbara Walter's application of reputation theory to self-determination movements has advanced our understanding of why many separatist movements result in armed conflict. Walter has shown that governments of multi-ethnic societies often respond to territorial disputes with violence to deter similar future demands by other ethnic groups. When governments grant territorial accommodation to one ethnic group, they encourage other ethnic groups to seek similar concessions. However, a number of recent empirical studies casts doubt on the validity of Walter's argument. We address recent challenges to the efficacy of reputation building in the context of territorial conflicts by delineating the precise scope conditions of reputation theory. First, we argue that only concessions granted after fighting should trigger additional conflict onsets. Second, the demonstration effects should particularly apply to groups with grievances against the state. We then test the observable implications of our conditional argument for political power-sharing concessions. Using a global sample of ethnic groups in 120 states between 1946 and 2013, we find support for our arguments. Our theoretical framework enables us to identify the conditions under which different types of governmental concessions are likely to trigger future conflicts, and thus has important implications for conflict resolution.
\end{abstract}




\section{Introduction}

In path-breaking work on self-determination movements, Walter (2006b, 2009b) explains the violent nature of separatist conflicts by emphasizing the importance of reputation building for governments of multi-ethnic societies. Governments' concessions to the demands of one ethnic group for autonomy in multi-ethnic societies can inspire other ethnic groups to bring forward similar demands, and possibly trigger armed conflicts. Once one ethnic domino falls, many more will follow (Hale, 2000). ${ }^{1}$ The past behavior of governments, in the form of granting territorial concessions to early challengers, signals weak resolve and helps other groups to update their beliefs about the type of government they face. Therefore, governments of multi-ethnic societies have strong incentives to invest in reputation building. They are often willing to pay the costs of fighting early secessionist challengers to deter other groups from making similar demands in the future. Russia's long-term reluctance to grant independence to the Chechnians in the North Caucasus illustrates the logic of this argument.

Although reputation theory as applied to self-determination movements has advanced our understanding of secessionist conflict, important questions remain pertaining to the theory's empirical validity and its applicability to broader range of government concessions. First, a number of recent studies cast doubt on the role and consequences of reputation building in the context of territorial conflicts (Nilsson, 2010; Forsberg, 2013; Sambanis, Germann \& Schädel, 2018). Second, territorial concessions constitute only one, albeit important, form of accommodation governments offer to ethnic groups. Political concessions, such as the inclusion of formerly excluded ethnic groups in the government in the form of power-sharing, provide another viable alternative. ${ }^{2}$ Do political powersharing concessions exhibit reputational dynamics similar to territorial concessions as

\footnotetext{
${ }^{1}$ We use domino effects and demonstration effects interchangeably.

${ }^{2}$ The two type of concessions this study focuses on have been labeled in various ways. Political powersharing is variably known as central or governmental power-sharing, inclusion, or the grand coalition. We use the term inclusion and power-sharing interchangeably to refer to formal and informal executive coalitions that encompass de facto representatives of at least two ethnic groups. Similarly, territorial concessions have been labeled ethnic federalism, regional autonomy, and territorial power-sharing. We use the term territorial concessions and autonomy interchangeably to denote any arrangement that gives leaders of one ethnic group meaningful levels of self-governance in a specific area.
} 
demonstrated by Walter (2009b)? Case study evidence from Africa's Great Lakes region suggests that granting power-sharing triggers similar detrimental domino effects as granting autonomy (Tull \& Mehler, 2005). However, we do not have any systematic evidence whether these domino effects extend beyond a few cases in Africa.

In this article, we address questions regarding to the empirical validity of reputation theory in the context of territorial concessions by explicating the conditions under which we should observe violent ethnic domino effects. First, we argue that only concessions granted in response to violent challenges should inspire additional territorial armed conflicts. While concessions granted in peacetime may signal low governmental resolve, they do not prove rebellion as an effective strategy. Second, we argue that not all ethnic groups in a state respond equally to witnessing concessions. Only those groups with existing grievances against the government would have incentives to rebel in reaction to the accommodation of the demands of another ethnic group.

Our conditional argument explains some of the inconsistent empirical support for Walter's argument. Using a sample of politically relevant ethnic groups included in the Ethnic Power Relations dataset (EPR) between 1946 and 2013 (Cederman, Wimmer \& Min, 2010; Vogt et al., 2015), we find that autonomy concessions are indeed associated with additional territorial civil war onsets, in line with Walter (2006b, 2009b). However, violent domino effects only occur if governments granted the concession to a violent challenger. Territorial concessions granted during peaceful periods do not seem to trigger additional rebellions. On the challenger side, our results indicate that only groups with neither autonomy nor access to governmental power take up arms for greater self-rule when other groups gain it after fighting. Therefore, we demonstrate that the support for the reputation theory seems to be neither as broad as Walter assumes nor as weak as Forsberg claims.

In addition to accounting for the inconsistent empirical support for reputation theory in the context of territorial concessions, our conditional approach uncovers a similar conditional dynamic for power-sharing concessions. Granting inclusion only triggers demonstration effects after wars and only by excluded groups. This is an important insight 
not only because power-sharing has emerged as one of the most common mechanisms of conflict resolution since the end of the Cold War (Hartzell \& Hoddie, 2007: 54), but also because more and more scholars agree on its effectiveness in preventing civil war recurrence (Lijphart, 1977; Hartzell \& Hoddie, 2007; Mattes \& Savun, 2009).

Our study thus contributes to a growing literature on conflict resolution and secessionist conflicts that extends Walter's insights. Cunningham (2011), for example, studies the strategic choices governments face when dealing with multiple factions within one selfdetermination movement rather than between multiple independent challengers. Building more directly on reputation theory, Griffiths (2015) argues that the success of one secessionist movement depends on the number of additional challengers with preexisting administrative units rather than on the number of all challengers. We join these studies by emphasizing a conditional approach to reputation theory but differ in two respects. For one, similar to Walter (2006b) and Cunningham (2013a) we study the perspective of potential challengers rather than governments. Second, we investigate armed conflict rather than the success of self-determination movements as the most concerning outcome of self-determination movements.

\section{Reputation theory and territorial civil war}

Reputation theory, first developed in economics, describes attempts of firms to keep potential competitors out of the market. Fierce price competition, which deters market entry by potential rivals, originally hurts already existing firms but shields them from competition in the long run. Walter adopts this theory to explain self-determination conflicts between a government and an ethnic minority over control of territory and argues that governments often hesitate to settle territorial demands peacefully. The reason for choosing violent confrontation over compromise lies in governments' fears that settlement will trigger domino effects. Governments prefer fighting to send potential challengers a signal of high resolve, and thus deter future demands and armed conflict.

Although Walter is not the first scholar to examine government's reputation with re- 
gard to territorial civil wars (for example, Toft, 2002, 2003), she develops and tests the theory in the most systematic fashion. Walter (2009b: 13-15) identifies four conditions under which reputation theory applies to the interactions between governments and ethnic minorities. First, reputation theory requires repeated play of government-minority interactions and thus only operates when granting concessions to one ethnic group today raises the possibility of future demands by other potential challengers. Second, issue specificity necessitates that both the actions and the actors should be sufficiently similar to one another, and that potential challengers should be able to observe the relevance of concessions granted to another actor to their own situation. Third, observability means that government behavior is visible and public to observing groups. Fourth, incomplete information is an important precondition of reputation logic for two reasons. First, initial challenger hide their true fighting capability to attract outside funding or extract a better deal from negotiations while the government will fight early challengers to distinguish strong from weak and bluffing rebels (Walter, 2009a: 247-249). Second, even after witnessing concessions to other rebels, potential challengers do not know with certainty if they are facing a resolved government that had to give in to a strong challenger or an uncommitted incumbent with low resolve. Simultaneously, these 'uncommitted governments have strong incentives to behave as if they were tough, at least against early challengers' (ibid., 250).

With these scope conditions in place, the reputation argument proceeds in seven steps: (1) the initial challenger demands a concession, (2) the government decides whether to concede, (3) the initial challenger rebels or not, (4) the government responds by conceding or not, (5) a potential challenger witnesses the preceding actions and demands a concession, (6) the government again decides how to respond, and (7) the potential challenger rebels or acquiesces. ${ }^{3}$ Walter (2006a) finds that governments are less likely to concede initially (steps 2 or 4) when they expect further demands later on. This result supports the notion that governments act strategically and consider the implications of their actions in steps 5-7. Walter (2006b) also presents evidence in favor of reputation theory's

\footnotetext{
${ }^{3}$ We are grateful to an anonymous reviewer for the suggestion to divide the reputation argument into these seven steps.
} 
implications for ethnic groups, which are more likely to violently seek self-determination (step 7) after witnessing concessions earlier (steps 2 or 4 ). ${ }^{4}$ Thus, some governments either miscalculate or face other constraints which necessitate earlier concessions. ${ }^{5}$

Recent studies question the empirical validity of Walter's conclusions (Nilsson, 2010; Forsberg, 2013; Sambanis, Germann \& Schädel, 2018). The most direct empirical challenge to the efficacy of reputation building comes from Forsberg (2013: 338), who shows that 'ethnic groups are not more predisposed to pursuing violent conflict when other groups in the proximity are successful in the pursuit of their separatist demands.' Like Walter (2006b), Forsberg investigates the likelihood of violent challenges (step 7) but only in the post-Cold War period. Unlike Walter, Forsberg's analysis only considers concessions granted in response to armed rebellion (step 4) rather than violent and non-violent tactics (steps 2 or 4). ${ }^{6}$ Using a new dataset on secessionist demands, Sambanis, Germann \& Schädel (2018) fail to substantiate the validity of reputation theory with respect to governments' decision to accommodate or deny demands for self-determination in multiethnic societies (step 2) and conclude that 'governments may still care to set a precedent, but only under a set of conditions that have not yet been specified' (p.26). ${ }^{7}$

Do ethnic dominoes fall or don't they? What explains these inconsistent findings? Plausible answers include differences between the Cold War and post-Cold War period on which Forsberg's and Nilsson's null findings depend and selection bias in the Minorities at Risk (MAR) data used by Walter but not by her critics. Selection bias could affect the type of concessions governments make as well as the recipients of these concessions and mask heterogeneous treatments. For example, some concessions might be costlier than others and the sample of ethnic groups in the MAR data may exhibit a higher propensity to rebel than majority groups not at risk of discrimination (cf. Hug, 2013).

We argue that a more explicit recognition of the scope conditions of reputation theory

\footnotetext{
${ }^{4}$ Walter does not distinguish between concessions made in response to initial demands (step 2) and those that occurred after an initial challenger rebelled (step 4).

${ }^{5}$ Walter (2006b) analyzes only armed responses to government concessions (step 7), while she jointly investigates non-violent and violent responses (steps 5 or 7 ) in her $2009 \mathrm{~b}$ book.

${ }^{6}$ Similarly, Nilsson (2010) finds no support for reputation theory in the context of negotiated settlements in multi-party armed conflicts.

${ }^{7}$ Griffiths (2015) specifies the administrative architecture of states as one condition that affects governments' reactions to self-determination demands.
} 
helps explain why some authors, in particular Forsberg (2013), fail to substantiate Walter's argument. We proceed by specifying the conditions under which we should expect territorial concessions to trigger additional armed conflict by other ethnic groups. To further evaluate the explanatory power of our conditional argument, we then examine whether other forms of governmental concessions, such as power-sharing, exhibit similar domino effects. ${ }^{8}$

\section{Conditions of ethnic domino effects}

Out of reputation theory's four basic conditions, we argue that issue specificity is instrumental in predicting when armed conflicts erupt in response to witnessing government concessions. Issue specificity necessitates that both the actions and the actors should be sufficiently similar to one another. We contend that similarity in actions implies that only concessions in response to armed conflict will trigger additional rebellions. Fighting an internal armed conflict constitutes a high-risk undertaking with an uncertain outcome, and endangers the lives of both rebels and civilians who live in conflict zones (Kalyvas \& Kocher, 2007). Rebelling requires not only the desire to obtain concessions but also the promise of success to offset the costs of fighting. When the government validates such beliefs, the imitation of a similar strategy is far more likely than when the government turns down any violent challenge but rewards non-violent tactics.

Our argument specifically applies to violent demonstration effects and contrasts with an alternative reading of reputation theory which emphasizes that governments fight early challengers exactly to demonstrate that concessions require bearing the costs of fighting. Giving away concessions to non-violent challengers 'for free' should thus encourage many more demands for concessions, some of them violent, as the government reveals its low resolve (Walter, 2009b: 27). Although governments may accommodate some challengers, eventually even low resolve governments will not be willing to share ever more power and

\footnotetext{
${ }^{8}$ In this study, we are interested in violent domino effects, i.e., whether governmental concessions encourage future rebellion, rather than non-violent tactics, by other ethnic groups. We explicitly describe tactics and challengers as non-violent rather than peaceful because groups that do not fight might still threaten violence.
} 
spoils, and decide to fight less deserving or weaker challengers. Existing research does not distinguish between these two interpretations as Walter (2009b: 130) tests the combined effect of territorial concessions extended to both non-violent and violent challengers. ${ }^{9}$

Our theoretical logic that emphasizes the similarity of actions by early and subsequent challengers is consistent with Chenoweth and Stephan's theoretical explanation for the generally higher success rate of non-violent movements relative to their violent counterparts. Non-violent movements enjoy a 'participation advantage' over violent rebellions due to lower entry costs for individuals, and thus attract more followers who put more pressure on the incumbent government (Chenoweth \& Stephan, 2011: 21). Only if the government affirms that individuals have to pay the costs of violent conflict to gain concessions will they engage in it.

Case evidence from India further supports our claim with regard to issue specificity. In the 1950s, multiple largely peaceful movements for linguistic self-determination in India's Hindu mainland triggered additional demands for regional autonomy among linguistic lines but no organized armed conflict. The Indian government under Nehru only conceded to moderates that repudiated violence and thus strengthened those leaders who sought change by non-violent tactics - a policy which indirectly deterred violence as successful road to accommodation. In contrast, when Indira Gandhi started to negotiate with extremist political actors in the late 1960s to weaken more moderate rivals in her own Congress Party, violent movements for autonomy spread across several northeastern states (Brass, 1991: 204-205). Arguing along similar lines, Wilkinson (2000: 789) quotes a Bodo rebel leader explaining the choice for violence in 1989: The 'central government agrees to negotiate only with those groups that show their force... The signing of accords with the Mizo National Front, the Tripura National Volunteers, and the Gorkha National Liberation Front shows that New Delhi has approved the methods employed for their objectives.'

$H_{1}$ : Territorial concessions granted post-conflict to an ethnic group increase the risk

\footnotetext{
${ }^{9}$ Walter (2006b) and Forsberg (2013) both only test the consequences of concessions granted to violent challenges.
} 
of civil war onsets by other ethnic groups. ${ }^{10}$

The issue specificity condition also applies to actors. It is unlikely that past concessions have uniform effects on all ethnic groups in the society. The set of potential challengers in a multi-ethnic society is more likely to include groups with grievances against the government than groups satisfied with the status quo. Conflict researchers have extensively documented the effect of grievances on the likelihood of civil war onset (for example, Gurr, 2000; Cederman, Wimmer \& Min, 2010). While Walter (2006b: 107108) explicitly outlines grievances as an alternative explanation to her reputation-based argument, we focus on the interaction between the two hypotheses. In our argument, grievances of potential challengers serve as a moderating variable between witnessing concessions to one group and violent demonstration effects.

In the context of territorial concessions, aggrieved potential challengers lack both territorial autonomy and they must be excluded from the central government. Our intuition builds on Lacina's insight that political power-sharing at the center increases ethnic groups' chances of realizing their preferences in the periphery (Lacina, 2014). Thus, domino effects after territorial concessions to one group should be particularly applicable to excluded and non-autonomous groups.

$H_{2}$ : Territorial concessions granted post-conflict to an ethnic group increase the risk of civil war onsets by other excluded and non-autonomous ethnic groups.

Whereas Walter (2006a,b, 2009b), Forsberg (2013), and others only consider autonomy concessions when studying reputation theory, governments extend other forms of accommodation to opposition groups. Since the end of the Cold War, power-sharing has become far more common than territorial concessions. Given its widespread use and strong endorsement by the international community, it is important to have a systematic understanding of potential perverse effects of power-sharing. The only empirical evidence for the presence of domino effects of power-sharing comes from Tull \& Mehler (2005) who show that the extension of political power-sharing triggered additional rebellions in Africa's Great Lakes' region.

\footnotetext{
${ }^{10}$ The reference group in all the hypotheses is no concessions.
} 
We do not have a strong theoretical reason to expect that the efficacy of reputation building should differ between territorial and power-sharing concessions. Gaining inclusion into the government coalition constitutes a particularly valuable price in socalled neopatrimonial states where clientelist practices dominate and holding governmental positions often constitutes the only possibility for elites to gain access to considerable economic resources and redistribute them to their co-ethnics (Lemarchand, 1972; Bates, 1974; Evans, 1989). If power-sharing enables access to rents, such concessions should have strong demonstration effects for other groups.

Moreover, the conditions of reputation theory developed with respect to territorial concessions should similarly apply to power-sharing concessions. Governments of multiethnic societies will likely engage in similar interactions with multiple groups sequentially or simultaneously when negotiating government access and thus satisfy the repeated play condition. With respect to the issue specificity and observability criteria, granting powersharing to one ethnic group is a specific enough policy that potential challengers would like to claim for themselves and clearly constitutes a publicly observable event. Finally, granting power-sharing concessions also fulfills the condition of incomplete information. Once the government coalition changes, excluded groups do not possess complete information over its intentions or strength, which fulfills a primary precondition of civil war (Walter, 2009a: 250).

Yet, scholars such as Toft (2002) and Jarstad \& Nilsson (2008) argue that governments generally care more about territorial integrity. Therefore, autonomy concessions should be costlier than sharing power at the center, and matter more for governmental reputation. If this perspective proved correct, power-sharing concessions would send a noisy signal about government's resolve to potential challengers and hence may not encourage additional rebellion as much as territorial concessions. Other conflict researchers, however, emphasize costs such as ruling groups' vulnerability to coups when inviting rivals into the government (Roessler, 2011). On balance, it is unclear whether territorial or power-sharing carries higher costs for the government. Thus, we argue that the type of concessions should not have a systematically different effect on the efficacy of reputation 
building.

However, we once more stress that violent domino effects predominantly follow powersharing concessions under conditions similar to those we outlined above for autonomy concessions. Reiterating our argument on the similarity of actions, potential challengers need to know that rebellion pays. They are only more likely to resort to arms when witnessing power-sharing as a conclusion to armed conflict. Regarding the similarity of actors, power-sharing granted to one group highlights the perceived injustice of political inequality experienced by other aggrieved ethnic groups. In the context of power-sharing concessions, the set of potential challengers should only include those groups that are currently excluded from government power. ${ }^{11}$ We summarize our argument in two additional hypotheses:

$H_{3}$ : Political power-sharing concessions granted post-conflict to an ethnic group increase the risk of civil war onsets by other ethnic groups.

$H_{4}$ : Political power-sharing concessions granted post-conflict to an ethnic group increase the risk of civil war onsets by other excluded ethnic groups.

We conclude this section by considering three alternative theoretical explanations. Like our explanation, the first two competing arguments stress a conditional logic that depends on heterogeneity in the costliness of concessions and the relative capacities of governments and challengers. First, costlier concessions in terms of the value of territory or government positions granted to initial challengers might weaken the government and decrease the likelihood of defeating ethnic groups that would not have had the capacity to defeat the government prior to the concession. Yet cheaper concessions might raise the expectations of weaker groups that a even a limited deal with the government is possible. These countervailing arguments explain why Walter's findings on the relationship between the past and future value of territory and the likelihood of accommodation are mixed

\footnotetext{
${ }^{11}$ Influential models of coalition formation that stress rent-seeking may identify the potential challengers differently. As adding additional groups to the government coalition decreases the resources available to existing coalition members, already included groups may challenge the government violently after power-sharing concessions. See Bates (1974) and Bueno de Mesquita et al. (2003).
} 
(Walter, 2009b: 128). Nevertheless, variation in the costs of concessions could moderate reputation effects and we will explore it empirically.

Second, governments also suffer costs from fighting armed conflicts, which could reduce their capacity relative to potential challengers (e.g., Bormann \& Hammond, 2016: 590-591). Specifically, conflict outcomes could qualify our hypotheses on the effect of violent versus non-violent challenges $\left(H_{1,3}\right)$. Governments that do not win an armed conflict and then concede a settlement might be particularly vulnerable to violent domino effects. However, some governments defeat rebel organizations and offer a settlement to the defeated group to reduce grievances and the chances of conflict recurrence (see Mukherjee, 2006). This strategy might produce worse reputation effects as such conciliatory governments prove that fighting pays regardless of its outcome. Since governments frequently choose to 'divide and concede' to self-determination challengers (Cunningham, 2011), we need to explore this possibility systematically.

Third, unobserved actions of the government and potential challengers between initial concessions (step 1) and the onset of violent domino effects (step 7) could affect our conclusions. Governments that grant concessions without fighting (step 2) might trigger multiple additional violent and non-violent demands for concessions (step 5), which escalate to conflict (step 7) (Walter, 2009b: 27). This theoretical option biases our analysis against finding support for our first and third hypotheses, which state that only concessions in response to armed conflict (step 4) trigger violent domino effects (step 7). Additionally, our investigation of power-sharing concessions introduces the possibility that concessions change the government that subsequent challengers face. Newly included groups that just gained a concession by violence might be much less willing to share the hard-won spoils with even more groups. Adding a battle-hardened challenger to the ruling coalition also increases the government' fighting capacity and makes it more likely to reject demands by additional groups (step 6). This logic should also deter future challengers and thus reduce the likelihood of violent domino effects (step 7). Still, former enemies now sharing power might also engage in infighting and thus open up the opportunity for additional rebellions. Once more, we will explore this possibility below. 


\section{Data}

In order to test our hypotheses, we rely on the 2014 version of the Ethnic Power Relations (EPR) dataset (Cederman, Wimmer \& Min, 2010; Vogt et al., 2015), which includes politically relevant ethnic groups in the world between 1946 and 2013. Groups become politically relevant when leaders make political claims on their behalf or when the government politically discriminates against them. They can merge into larger umbrella groups or split into smaller sub-populations.

Following Walter's focus on 'armed self-determination challenges' (2006b: 106), our outcome variable is the onset of territorial ethnic civil war in a given year, as coded by the ACD2EPR dataset which links all EPR groups to rebel organizations in the UCDP/PRIO Armed Conflict Database (ACD) (Wucherpfennig et al., 2012; Gleditsch et al., 2002; Themnér \& Wallensteen, 2014). We code a new onset in years with at least 25 battle-deaths and no active fighting in the government-rebel dyad in the preceding two years. We only consider civil wars in which ACD rebel groups make an exclusive claim to fight on behalf of and recruit fighters from an ethnic group.

We also adopt the ACD distinction of territorial and governmental armed conflicts. Since the repeated play condition implies that multiple groups need to be in a position to challenge the government, reputation theory should predominantly apply to territorial civil wars, which are 'about control of part of the state (who should control it and how).'12 In contrast, governmental civil wars over control of the entire state usually feature one strong rebel group (Buhaug, 2006) and we expect ethnic groups that initiate governmental conflicts to be similar in size to the government itself. If governmental power-sharing ends these more symmetric conflicts, other ethnic groups in the country will likely be too weak to challenge the government and its new, powerful coalition partner. ${ }^{13}$

Turning to our explanatory variables, EPR codes the relative size and political access of all ethnic groups along two dimensions (Vogt et al., 2015: 1331-2). First, it categorizes groups according to whether they are included or excluded from executive bodies such

\footnotetext{
${ }^{12} \mathrm{http} / / /$ www.pcr.uu.se/research/ucdp/definitions/. Accessed on September 23rd, 2016.

${ }^{13}$ Nevertheless, whether or not reputation theory applies to governmental civil war onsets is an empirical question that we address below.
} 
as cabinets, royal courts, military juntas, and communist central committees. Second, EPR provides data on the regional autonomy of territorially concentrated groups, which covers both ethnic groups that wield substantial control over a federal units as well as less formal arrangements. ${ }^{14}$

Although EPR does not directly code peace agreements or constitutional provisions that protect minorities, its de facto assessment of political power-sharing and territorial autonomy captures both formal and less formal arrangements (Cederman et al., 2015: 360). Moreover, unlike more detailed data collections that focus on formal concessions in peace agreements (Hartzell \& Hoddie, 2007; Jarstad \& Nilsson, 2008), EPR captures concessions before and after civil wars, and includes ethnic groups that did not receive concessions, that is, potential challengers. Finally, data sources on self-determination movements provide no information on the type of concessions and cover fewer potential challengers than EPR (see Coggins, 2011; Cunningham, 2011).

Figure 1 summarizes all power-sharing and autonomy concessions in the EPR data. ${ }^{15}$ It shows that the majority of governments grant concessions to non-violent challengers (light grey) rather than rebelling ethnic groups (dark grey). Our sample of concessions to ethnic groups thus reflects findings by Chenoweth \& Stephan (2011) that non-violent movements are more successful in reaching their goals. Furthermore, autonomy concessions become less popular after 1990 while power-sharing concessions become far more frequent after the end of the Cold War (Hartzell \& Hoddie, 2007: 54). Out of 296 concessions recorded by the EPR data between 1946 and 2013, only nine cases involve both autonomy and power-sharing.

Following the conditions of reputation theory (Walter, 2009b: 11-15), we restrict the EPR sample to those states with more than two ethnic groups, thus excluding cases such as Rwanda and Burundi where domino effects are impossible. This leaves us with 723 ethnic groups in 120 states. In our sample, governments include between 1 and 14 groups (mean=2.2), and exclude between 0 and 55 groups $($ mean=4). We further drop ethnic groups currently involved in armed conflict and groups that monopolize power in a state

\footnotetext{
${ }^{14} \mathrm{EPR}$ codes the power structure at the first day of each year, and thus effectively lags all variables.

${ }^{15}$ We identify concessions by changes in the political status of groups within the previous year.
} 


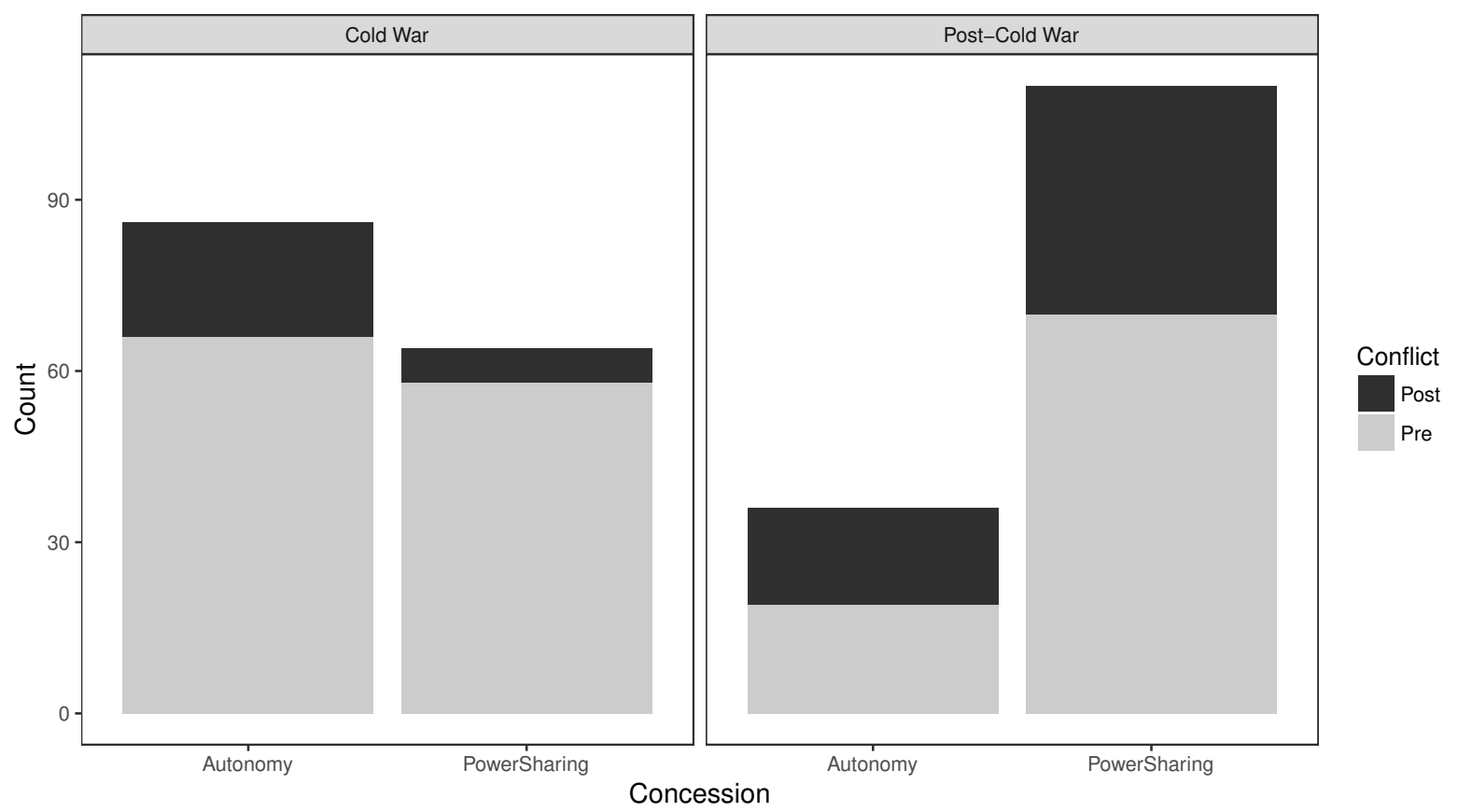

Figure 1. Autonomy and Power-Sharing Concessions in EPR

from the analysis. ${ }^{16}$

We create two indicator variables, one for territorial and one for power-sharing concessions. The autonomy dummy takes the value of 1 when one group witnesses another group receiving a territorial concession. Equivalently, we code the power-sharing dummy as 1 when one group witnesses another's inclusion into the central government. The initial values decay in subsequent years, so that the signal potential challengers receive weakens over time. Following Forsberg (2013: 333), we implement a 3-year half-life, which means that three years after the concession, any observing group will be assigned a value of 0.5 and after another three years a value of 0.25 . All years prior to a concession receive a value of 0 , and we reset the decay function once a government grants a new concession. Arguably, the most recent government behavior should exert the strongest effect on potential challengers' decision to rebel. To test our first hypothesis, which states that only post-conflict concessions should trigger domino effects, we compute two half-life functions for concessions granted before and after armed conflict.

One important threat to inferring the correct relationship between concessions and

\footnotetext{
${ }^{16}$ By definition, a group that has monopolized state power cannot fight an ethnic civil war. If several groups share government power as in Lebanon before 1975, intra-governmental conflicts are of course possible.
} 
the likelihood of additional onsets is the possibility of revenge. Where ethnic groups lose political power after armed conflicts, such as the Whites to the Shona in Zimbabwe in 1979, they would still witness a 'concession' to other groups. Clearly, this is not comparable to a case where the government includes an additional partner without losing influence. In contrast, the losing side will be more likely to rebel in reaction to their status loss. To control for such dynamics, we include a variable that measures whether potential challengers have been downgraded in the past two years.

Additionally, our models include common control variables from the literature such as exclusion from government power, existing regional autonomy arrangements, and group size. Exclusion should increase the risk of new civil wars (Gurr, 2000; Cederman, Wimmer \& Min, 2010). The effect of regional autonomy remains contested in the literature with some scholars claiming that it reduces conflict risk (Gurr, 2000; Jarstad \& Nilsson, 2008), while others argue that it provides groups with the institutional resources to rebel (Bunce, 1999). Our group size variable captures the ratio between the potential challenger and the government. ${ }^{17}$ As ethnic groups enter into a ruling coalition, for example after a government grants power-sharing to an initial violent challenger, this variable decreases for the individual ethnic group, and we thus control for changes in the government composition. Civil war onsets should become more likely with increasing group size, which reflects a higher capacity to challenge the government.

To account for temporal effects, we control for the number of armed conflicts a group has previously fought against the government. Existing research suggests that this variable captures feelings of revenge and resentment resulting from prior episodes of civil war, and we thus expect it to increase the likelihood of recurrence (Cederman, Wimmer \& Min, 2010: 97). In addition, we employ the cubic polynomial of time since the last conflict or independence as peace years to account for non-linear temporal dynamics (Carter \& Signorino, 2010).

At the country-level, we employ lagged and logged GDP per capita and population size variables (Hunziker \& Bormann, 2013). In line with existing findings, we expect

\footnotetext{
${ }^{17}$ Should the group itself be part of the government, the ratio is calculated with respect to the remaining government group(s).
} 
poorer and larger states to face a higher risk of rebellion (Hegre \& Sambanis, 2006). To account for the potential cost of concessions, we include the number of ethnic groups in a state. In light of the poor quality of data on land value (also see Sambanis, Germann \& Schädel, 2018), Walter (2009b: 26) argues that the number of ethnic groups in a country is 'a reliable proxy for the amount of land that could come under dispute, and therefore, the relative value of different pieces of territory to the government.' She suggests that more potential challengers make the government more determined to avoid concessions that could entail additional demands, which in turn implies that groups should recognize that fighting will not pay. Finally, we control for the number of other armed conflicts a government fought in the past year to control for decreasing state capacity as an alternative explanation of domino effects. ${ }^{18}$

\section{Analysis}

We test our hypotheses by estimating logistic regression models with country-clustered standard errors. To ensure that the estimated associations between our main explanatory variables and civil war onsets do not result from high-dimensional correlations with other variables, we first display a simple base model that only includes the main explanatory variable but no controls other than peace years (Achen, 2005). This strategy also allows us to effectively demonstrate how much alternative explanations impact the original effect of our main explanatory variables.

\section{Territorial concessions and domino effects}

We begin by revisiting Forsberg and Walter's debate. Unlike Walter, we test the effect of autonomy concessions on the likelihood of additional armed conflict onsets but not on other less violent tactics. In contrast to Forsberg, we analyze all years between 1946 and 2013 rather than only the post-Cold War period. Additionally, our set of autonomy concessions extends beyond peace agreements by also encompassing territorial arrangements

\footnotetext{
${ }^{18}$ Descriptive statistics are available in the online appendix.
} 
made before the outbreak of hostilities or outside of negotiated settlements. As opposed to either study, we specifically explore our conditional framework.

Table I presents four models that link autonomy concessions to territorial armed conflict onset by potential ethnic challengers. Model 1 includes all concessions in our sample but excludes all control variables except for peace years. Model 2 adds those controls and thus provides a specification similar to Walter's and Forsberg's tests. Models 3 and 4 test our conditional arguments as described by $H_{1,2}$. The estimated effects of all autonomy concessions in Models 1 and 2 reveals a strongly positive effect on additional civil conflicts in line with Walter's original results (Walter, 2009b: 125-132). Although the size of the effect drops by half, once we add our control variables in Model 2, both estimates are significantly different from zero.

Model 3 demonstrates that the general effect of all autonomy concessions predominantly derives from those granted in response to fighting, which provides modest support for $H_{1}$ as the average effect dissipates quickly after the concession. Territorial autonomy granted before armed conflict is unlikely to trigger additional ethnic rebellions. ${ }^{19}$ Model 4 evaluates $H_{2}$, which predicts that only non-autonomous and excluded groups are more likely to rebel after witnessing autonomy granted to another group. The estimated interaction coefficient more than doubles relative to the baseline specification in Model 2 and is estimated with high precision.

To facilitate the substantive interpretation of these results, we simulated the difference in the likelihood of territorial civil war onset by a potential challenger that witnesses concessions compared to one that does not. Figure 2 displays the shift in the predicted probabilities of violent domino effects for excluded groups with and without autonomy that do not witness a territorial concession to those that do $\left(H_{2}\right)$. In the first year after a concession, the likelihood of additional territorial onsets increases by more than 2.5 percentage points relative to the baseline for groups without any preexisting accommo-

\footnotetext{
${ }^{19}$ While the average effect of pre-conflict autonomy in Model 3 is negative, it has a sizable standard error. Due to this large uncertainty we can only reject the null of no difference between post-conflict and pre-conflict autonomy concessions in a one-sided test. Like Walter, we are interested in the counterfactual difference between witnessing and not witnessing concessions and confidently reject the null hypothesis of no difference.
} 
Table I. Autonomy concessions (3-year half-life) and territorial ethnic civil war onset, 1946-2013

\begin{tabular}{|c|c|c|c|c|}
\hline & $(1)$ & $(2)$ & $(3)$ & $(4)$ \\
\hline Autonomy Concession & $\begin{array}{c}2.734^{* * *} \\
(0.504)\end{array}$ & $\begin{array}{c}1.371^{* * *} \\
(0.247)\end{array}$ & & \\
\hline Post-Conflict Autonomy Conc. & & & $\begin{array}{l}1.289^{* *} \\
(0.452)\end{array}$ & $\begin{array}{l}-0.364 \\
(0.483)\end{array}$ \\
\hline Pre-Conflict Autonomy Conc. & & & $\begin{array}{l}-0.315 \\
(0.804)\end{array}$ & \\
\hline Post-Conf. Aut. Conc. $\times$ Excl. $\times \sim$ Aut. & & & & $\begin{array}{c}3.067^{* * *} \\
(0.878)\end{array}$ \\
\hline Excluded & & $\begin{array}{c}1.169^{* * *} \\
(0.296)\end{array}$ & $\begin{array}{c}1.156^{* * *} \\
(0.290)\end{array}$ & $\begin{array}{c}1.086^{* * *} \\
(0.290)\end{array}$ \\
\hline Downgraded & & $\begin{array}{l}0.943^{*} \\
(0.460)\end{array}$ & $\begin{array}{c}0.889 \\
(0.459)\end{array}$ & $\begin{array}{c}0.857 \\
(0.454)\end{array}$ \\
\hline Autonomy & & $\begin{array}{l}0.585 \\
(0.303)\end{array}$ & $\begin{array}{l}0.635^{*} \\
(0.307)\end{array}$ & $\begin{array}{l}0.827^{* *} \\
(0.295)\end{array}$ \\
\hline Relative Size & & $\begin{array}{l}-0.280 \\
(0.623)\end{array}$ & $\begin{array}{l}-0.282 \\
(0.615)\end{array}$ & $\begin{array}{l}-0.204 \\
(0.590)\end{array}$ \\
\hline Past Civil Wars & & $\begin{array}{c}0.592^{* * *} \\
(0.150)\end{array}$ & $\begin{array}{c}0.606^{* * *} \\
(0.140)\end{array}$ & $\begin{array}{c}0.614^{* * *} \\
(0.141)\end{array}$ \\
\hline $\log (\#$ of Groups) & & $\begin{array}{l}-2.268^{* * *} \\
(0.458)\end{array}$ & $\begin{array}{c}-2.233^{* * *} \\
(0.458)\end{array}$ & $\begin{array}{c}-2.304^{* * *} \\
(0.468)\end{array}$ \\
\hline Ongoing Civil War & & $\begin{array}{l}0.760^{*} \\
(0.327)\end{array}$ & $\begin{array}{l}0.748^{*} \\
(0.333)\end{array}$ & $\begin{array}{l}0.734^{*} \\
(0.336)\end{array}$ \\
\hline Log(GDP p.c.) & & $\begin{array}{l}-0.213 \\
(0.111)\end{array}$ & $\begin{array}{c}-0.231^{*} \\
(0.107)\end{array}$ & $\begin{array}{l}-0.215 \\
(0.115)\end{array}$ \\
\hline $\log ($ Population $)$ & & $\begin{array}{c}0.332^{* * *} \\
(0.095)\end{array}$ & $\begin{array}{l}0.338^{* *} \\
(0.104)\end{array}$ & $\begin{array}{c}0.348^{* *} \\
(0.113)\end{array}$ \\
\hline Peace Years & $\begin{array}{c}-0.269^{* * *} \\
(0.052)\end{array}$ & $\begin{array}{c}-0.312^{* * *} \\
(0.057)\end{array}$ & $\begin{array}{c}-0.319^{* * *} \\
(0.056)\end{array}$ & $\begin{array}{c}-0.324^{* * *} \\
(0.058)\end{array}$ \\
\hline Peace Years ${ }^{2}$ & $\begin{array}{c}0.008^{* * *} \\
(0.002)\end{array}$ & $\begin{array}{c}0.012^{* * *} \\
(0.003)\end{array}$ & $\begin{array}{c}0.012^{* * *} \\
(0.003)\end{array}$ & $\begin{array}{c}0.012^{* * *} \\
(0.003)\end{array}$ \\
\hline Peace Years ${ }^{3}$ & $\begin{array}{c}-0.0001^{* * *} \\
(0.000)\end{array}$ & $\begin{array}{c}-0.0001^{* * *} \\
(0.000)\end{array}$ & $\begin{array}{c}-0.0001^{* * *} \\
(0.000)\end{array}$ & $\begin{array}{c}-0.0001^{* * *} \\
(0.000)\end{array}$ \\
\hline Constant & $\begin{array}{c}-3.465^{* * *} \\
(0.243)\end{array}$ & $\begin{array}{c}-6.830^{* * *} \\
(1.746)\end{array}$ & $\begin{array}{c}-6.796^{* * *} \\
(1.858)\end{array}$ & $\begin{array}{c}-7.035^{* * *} \\
(2.006)\end{array}$ \\
\hline $\mathrm{N}$ & 29,653 & 27,011 & 27,011 & 27,011 \\
\hline$\ell$ & -827.716 & -611.069 & -611.574 & -607.428 \\
\hline $\mathrm{AIC}$ & $1,665.432$ & $1,250.138$ & $1,253.148$ & $1,244.855$ \\
\hline
\end{tabular}

${ }^{*} \mathrm{p}<0.05 ;{ }^{* *} \mathrm{p}<0.01 ;{ }^{* * *} \mathrm{p}<0.001$

Country-clustered standard errors in parentheses. 
dation. $^{20}$ The negative reputation effect of granting autonomy concessions diminishes as the time to the concession increases and reaches almost zero after ten years. The effect is non-existent for groups that already enjoy either territorial autonomy or inclusion. ${ }^{21}$
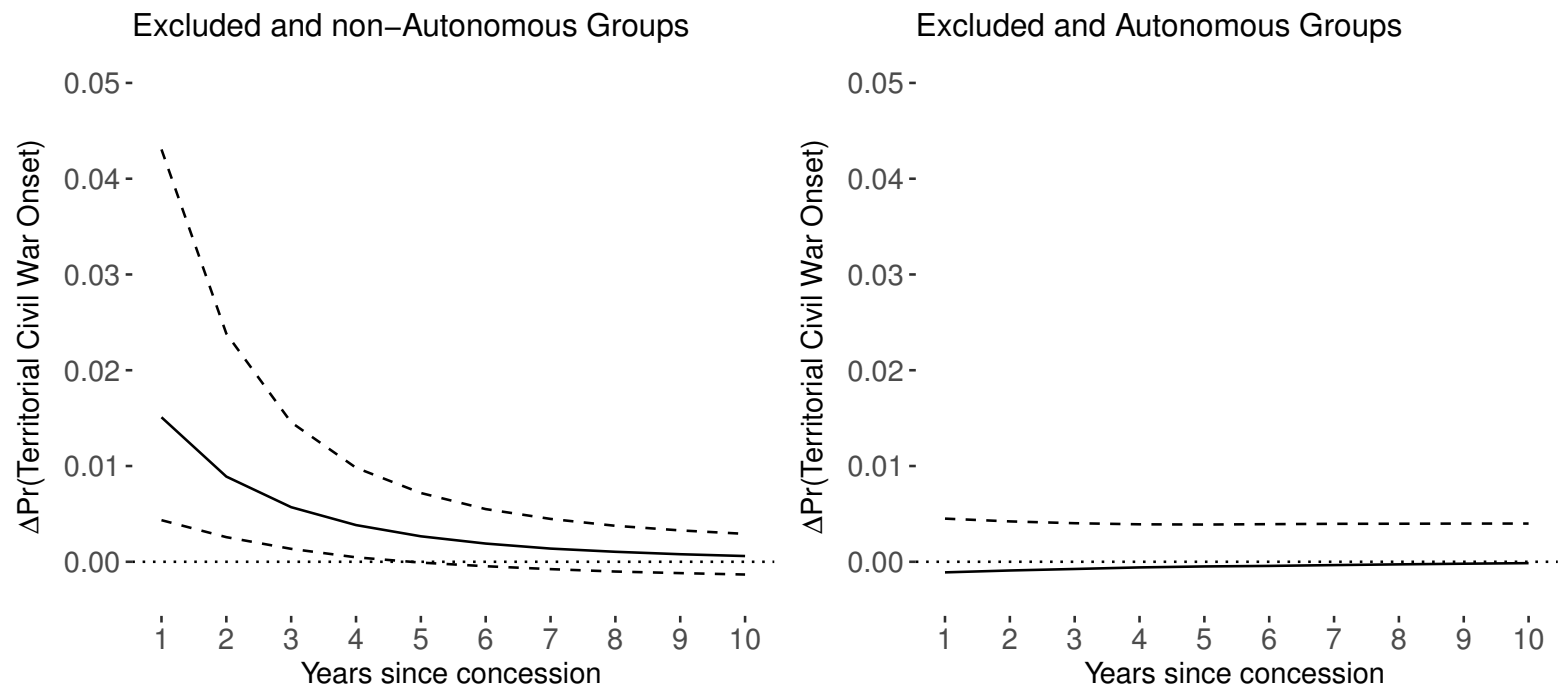

Figure 2. Differences in territorial onset probability between witnessing and not witnessing post-conflict autonomy concessions for excluded groups by autonomy status

Before turning to domino effects after power-sharing concessions, we briefly discuss the estimated effects of our control variables. Exclusion from government power, a history of past conflict, ongoing civil wars in the territory of the state, and a higher population increase the likelihood of new onsets. As predicted by Walter, countries with a higher number of potential challengers experience a lower risk of additional civil wars in Models 2 through 4. Our estimates of the downgraded and the GDP per capita variables point to the expected directions but remain statistically insignificant at the .05-level in two of three models.

Two estimated effects do not align with previous findings. For one, we consistently find a negative and statistically insignificant estimate of group size, which may derive from our focus on territorial civil wars that involve smaller challengers. For another, regional autonomy makes ethnic groups more likely to rebel rather than less. This finding

\footnotetext{
${ }^{20}$ We show the median predicted probability of one additional territorial onset along with the 5 th and 95th percentiles out of 2,000 simulated draws from a multivariate normal distribution defined by our estimated coefficients from Model 4, and the control variables set to their mean or median values.

${ }^{21}$ Our appendix contains graphical interpretations of both $H_{1}$ and $H_{2}$. See Figures A2 and A3.
} 
either reflects the double-edged sword of territorial power-sharing that not only assuages grievances but also provides the organizational resources to stage a rebellion (Roeder, 1991; Bunce, 1999), or the potential endogeneity of autonomy to conflict risk (Grigoryan, 2012).

\section{Political power-sharing concessions and domino effects}

Proceeding in the same order as above, Model 5 in Table II shows that governments that grant political power-sharing increase the risk of violent domino effects. Model 6 adds control variables which slightly reduce the estimated effect size of power-sharing concessions while increasing the estimated standard error. Yet we continue to find a positive and statistically significant effect of power-sharing concessions on the likelihood of additional civil war onsets by potential challengers.

Model 7 tests $H_{3}$ by distinguishing between power-sharing concessions granted to non-violent challengers and those granted to violent challengers. Whereas our estimate of post-conflict concessions continues to exert a strongly positive effect on additional territorial onsets, concessions granted before the outbreak of hostilities have no meaningful impact on potential challengers' likelihood to rebel. A two-sided t-test reveals statistically significant differences between concessions granted before and after the outbreak of armed conflict at the .1 level. In Model 8, we narrow our focus to post-conflict power-sharing concessions and, in accordance with $H_{4}$, find that only excluded groups are associated with a higher risk of subsequent rebellion. In contrast, included groups exhibit a negative and highly uncertain propensity to rebel when witnessing power-sharing concessions. A two-sided t-test demonstrates statistically significant differences between concessions granted to included and excluded potential challengers at the .1 level.

As before, we present substantive effects for witnessing post-conflict concessions and vary the political status of the potential challenger from political exclusion to inclusion in Figure $3\left(H_{4}\right)$. In the first year after a concession, the probability of additional territorial civil wars for excluded groups increases by almost two percentage points and then declines. In contrast, included groups witnessing post-conflict power-sharing experience no 
Table II. Political power-sharing (3-year half-life) and territorial ethnic civil war onset, 1946-2013

\begin{tabular}{|c|c|c|c|c|}
\hline & $(5)$ & $(6)$ & $(7)$ & $(8)$ \\
\hline Power-Sharing Concession & $\begin{array}{l}1.850^{* *} \\
(0.661)\end{array}$ & $\begin{array}{l}1.631^{*} \\
(0.767)\end{array}$ & & \\
\hline PS Post-Conflict Conc. & & & $\begin{array}{c}1.987^{* * *} \\
(0.569)\end{array}$ & $\begin{array}{l}-1.418 \\
(1.653)\end{array}$ \\
\hline PS Pre-Conflict Conc. & & & $\begin{array}{l}-0.249 \\
(0.972)\end{array}$ & \\
\hline PS Post-Conflict Conc. $\times$ Excl. & & & & $\begin{array}{l}4.099^{*} \\
(1.817)\end{array}$ \\
\hline Excluded & & $\begin{array}{c}1.185^{* * *} \\
(0.295)\end{array}$ & $\begin{array}{c}1.244^{* * *} \\
(0.305)\end{array}$ & $\begin{array}{l}1.008^{* *} \\
(0.315)\end{array}$ \\
\hline Downgraded & & $\begin{array}{c}0.826 \\
(0.473)\end{array}$ & $\begin{array}{c}0.831 \\
(0.480)\end{array}$ & $\begin{array}{c}0.770 \\
(0.483)\end{array}$ \\
\hline Autonomy & & $\begin{array}{l}0.664^{*} \\
(0.295)\end{array}$ & $\begin{array}{l}0.670^{*} \\
(0.290)\end{array}$ & $\begin{array}{l}0.712^{*} \\
(0.301)\end{array}$ \\
\hline Relative Size & & $\begin{array}{l}-0.306 \\
(0.636)\end{array}$ & $\begin{array}{l}-0.269 \\
(0.645)\end{array}$ & $\begin{array}{l}-0.352 \\
(0.675)\end{array}$ \\
\hline Past Civil Wars & & $\begin{array}{c}0.590^{* * *} \\
(0.141)\end{array}$ & $\begin{array}{c}0.575^{* * *} \\
(0.140)\end{array}$ & $\begin{array}{c}0.585^{* * *} \\
(0.138)\end{array}$ \\
\hline $\log (\#$ of Groups $)$ & & $\begin{array}{c}-2.198^{* * *} \\
(0.486)\end{array}$ & $\begin{array}{c}-2.172^{* * *} \\
(0.481)\end{array}$ & $\begin{array}{c}-2.224^{* * *} \\
(0.480)\end{array}$ \\
\hline Ongoing Civil War & & $\begin{array}{c}0.824^{*} \\
(0.346)\end{array}$ & $\begin{array}{l}0.823^{*} \\
(0.354)\end{array}$ & $\begin{array}{c}0.816^{*} \\
(0.347)\end{array}$ \\
\hline Log(GDP p.c.) & & $\begin{array}{l}-0.210 \\
(0.121)\end{array}$ & $\begin{array}{l}-0.203 \\
(0.118)\end{array}$ & $\begin{array}{l}-0.190 \\
(0.117)\end{array}$ \\
\hline Log(Population) & & $\begin{array}{l}0.351^{* *} \\
(0.113)\end{array}$ & $\begin{array}{c}0.354^{* *} \\
(0.115)\end{array}$ & $\begin{array}{c}0.356^{* *} \\
(0.110)\end{array}$ \\
\hline Peace Years & $\begin{array}{c}-0.243^{* * *} \\
(0.044)\end{array}$ & $\begin{array}{c}-0.310^{* * *} \\
(0.055)\end{array}$ & $\begin{array}{c}-0.312^{* * *} \\
(0.055)\end{array}$ & $\begin{array}{c}-0.306^{* * *} \\
(0.056)\end{array}$ \\
\hline Peace Years ${ }^{2}$ & $\begin{array}{c}0.007^{* * *} \\
(0.002)\end{array}$ & $\begin{array}{c}0.011^{* * *} \\
(0.003)\end{array}$ & $\begin{array}{c}0.012^{* * *} \\
(0.003)\end{array}$ & $\begin{array}{c}0.011^{* * *} \\
(0.003)\end{array}$ \\
\hline Peace Years ${ }^{3}$ & $\begin{array}{c}-0.0001^{* * *} \\
(0.000)\end{array}$ & $\begin{array}{c}-0.0001^{* * *} \\
(0.000)\end{array}$ & $\begin{array}{c}-0.0001^{* * *} \\
(0.000)\end{array}$ & $\begin{array}{c}-0.0001^{* * *} \\
(0.000)\end{array}$ \\
\hline Constant & $\begin{array}{c}-3.480^{* * *} \\
(0.247)\end{array}$ & $\begin{array}{c}-7.253^{* * *} \\
(2.004)\end{array}$ & $\begin{array}{c}-7.432^{* * *} \\
(2.053)\end{array}$ & $\begin{array}{c}-7.332^{* * *} \\
(2.046) \\
\end{array}$ \\
\hline $\mathrm{N}$ & 29,653 & 27,011 & 27,011 & 27,011 \\
\hline$\ell$ & -839.469 & -612.166 & -610.741 & -608.624 \\
\hline $\mathrm{AIC}$ & $1,688.938$ & $1,252.331$ & $1,251.482$ & $1,247.248$ \\
\hline
\end{tabular}

${ }^{*} \mathrm{p}<0.05 ;{ }^{* *} \mathrm{p}<0.01 ;{ }^{* * *} \mathrm{p}<0.001$

Country-clustered standard errors in parentheses. 


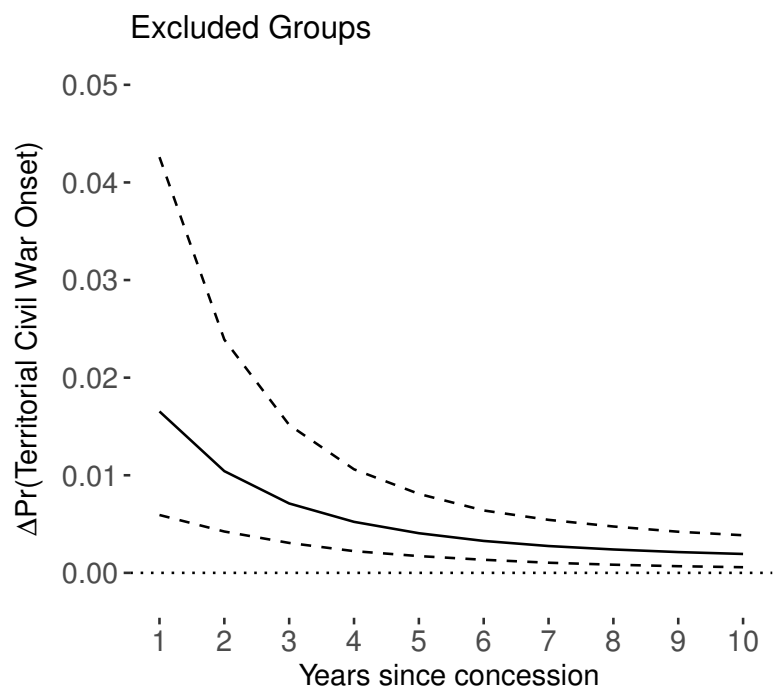

Included Groups

Figure 3. Differences in onset probability between witnessing and not witnessing postconflict power-sharing concessions for excluded (left) and included groups (right)

higher risk of conflict onset relative to the baseline of no concessions. Compared to the substantive effect of $H_{3}$, taking into account both concession type and challenger status increases the precision and duration of the perverse effect of power-sharing concessions (see Figure A4). ${ }^{22}$ Overall, these results allow us to reject the null hypothesis of no domino effects associated with political power-sharing concessions under the conditions described by $H_{4}$.

Comparing the effects of autonomy and power-sharing conditions, we find that their magnitudes do not differ much once we condition on political status (Models 4 and 8). However, the predicted probability of additional armed conflicts by any group after postconflict power-sharing exceeds the one after granting autonomy by almost an order of magnitude (Models 3 and 7). This difference partially explains the contradictory findings by Walter and Forsberg. As Forsberg does not consider conditional effects, her analysis misses the strong interactive effect of exclusion and witnessing concessions. In contrast, Walter's analysis builds on Gurr's Minorities at Risk data that disproportionately samples 'at risk' groups (Hug, 2013), which suggests parallels between the conditional effects suggested by our argument and Walter's focus on essentially excluded groups. In sum, the results presented above support a conditional interpretation of reputation theory for

\footnotetext{
${ }^{22}$ We find no difference between excluded groups that witness concessions to non-violent challengers relative to those that witness no concessions.
} 
both autonomy and power-sharing concessions.

\section{Robustness checks}

To probe the robustness of our results, we estimated a number of alternative model specifications presented in the online appendix. To rule out that either autonomy or power-sharing concessions pick up the effect of the other, we added both triggers to our main conditional models. While we find some increased uncertainty, the results continue to be both statistically and substantively significant for both power-sharing and autonomy concessions (Table A2). We also reject explanations that predict an increased risk of internal conflicts over government power after concessions, due to rebellions by disaffected outsiders or infighting (Tables A3 \& A4). According to our data, domino effects only apply to territorial or secessionist armed conflict.

As Figure 1 reveals different patterns of concessions during and after the Cold War, we probed whether domino effects vary by time period. Indeed we find that domino effects associated with power-sharing exclusively occur after 1990 (Table A2 \& Figure A5). This result fits Tull and Mehler's (2005) description of the perverse repercussions of powersharing concessions in Sub-Saharan Africa in response to the international community's turn towards power-sharing as a means of conflict resolution in the early 1990s. During the Cold War the United States and the Soviet Union variably supported many narrowbased regimes and relieved them from forming inclusive government coalitions to overcome domestic threats (Boix \& Svolik, 2013: 308; Cheibub \& Hays, 2017). Therefore, ethnic minority regimes were more common during the Cold War and governments did not need to extend political power-sharing concessions to stabilize their rule. In contrast, territorial concessions were much higher during the Cold War and the data show that domino effects associated with autonomy concessions were relevant mostly before 1990 (Table A2 \& Figure A6). These period effects further explain the null results found by Forsberg, who analyzes the period between 1989 and 2004. They also underline the importance of international actors for studying armed conflict in general (Kalyvas \& Balcells, 2010) and secession in particular (Coggins, 2011). 
We also explore the effect of two other conditions on violent domino effects: concession costliness and government capacity. Using the size of the receiving group as a proxy for concession costs, we find that larger territorial concessions only have a higher likelihood of triggering domino effects in the first year after a concession (Figure A7) and no significant effect for power-sharing concessions. Similarly, conflict outcomes, our proxy for variation in government capacity and coded on the basis of the link between the UCDP termination data by Kreutz (2010) and the non-state actor (NSA) dataset by Cunningham, Gleditsch \& Salehyan (2009), do not change our theoretical conclusions but provide interesting additional insights (Tables A7 and A8). Rebel victory consistently reduces the likelihood of domino effects and even perfectly predicts no conflict when combined with post-conflict autonomy concessions. Stalemates in the form of either negotiated settlements or ceasefires slightly increase the risk of additional challenges but do not reach statistically significant results. Although our estimate of government victory indicates that it deters additional armed conflicts by other ethnic groups, it fails to reach statistical significance in almost all specifications. Yet, when we interact post-conflict autonomy concessions and government victory, we find that this strategy of 'defeat and concede' has a strong positive effect on additional armed conflict onsets.

Additional robustness checks include alternative half-life specifications (Tables A9A12), hierarchical models with random intercepts at the country and year-level (Tables A13 \& A14), and linear probability models with group-fixed effects (Table A15). Our results remain robust throughout the vast majority of these specifications. Only the hierarchical framework reveals slightly greater uncertainty for domino effects after both territorial and power-sharing concessions, and hence slightly diminishes our confidence in $H_{2}$ and $H_{3}$. As the most conservative group-level fixed effects models show support for all our hypotheses, we remain confident that our results present reliable estimates. 


\section{Conclusion}

Preventing civil wars remains a tremendous challenge for war-prone countries. One ostensibly straightforward strategy governments can adopt is to appease opposition by extending concessions. However, Walter argues that forward-looking governments of multi-ethnic societies have an incentive to avoid extending territorial concessions to early challengers to signal resolve and thus reduce the risk of future violent challenges. Building on Walter's reputation theory, we outline the conditions under which territorial concessions should be more likely to generate violent domino effects. First, only concessions granted in response to violent challenges should inspire future rebellion. Second, only those groups with existing grievances against the government would have incentives to rebel in reaction to the accommodation of the demands of another ethnic group.

Our conditional argument also uncovers a similar dynamic for non-territorial concessions. Power-sharing concessions trigger additional conflicts only if they are granted after wars and only by excluded groups. Put differently, neither territorial nor powersharing concessions incite additional territorial armed conflicts if governments grant them to non-violent challengers and if other ethnic groups' grievances are addressed through pre-existing autonomy or power-sharing.

Our findings have several important policy implications. For one, promoters of powersharing institutions as a conflict resolution tool need to be aware of the potential perverse consequences of political power-sharing when it does not extend to all groups in a country. This calls for an encompassing approach to creating post-war peace arrangements as advocated by Lijphart (1977) rather than partial power-sharing institutions that do not include all politically relevant ethnic groups. If only partial peace is possible (Nilsson, 2008), the international community should not only monitor former conflict actors and regions but also potential challengers in the same state - particularly in the initial two to three years after concessions, when the risk of domino effects peaks.

Additionally, granting autonomy or sharing political power before civil war breaks out does not seem to trigger violent domino effects but may still motivate additional demands for self-determination. In order to avoid the detrimental humanitarian consequences of 
internal armed conflicts, the international community should continue to push ethnically exclusive regimes to share power during nonviolent times. As many theories of ethnic politics predict that political elites will be loathe to sharing power (Bates, 1974; Bueno de Mesquita et al., 2003), conflict researchers should dedicate more attention towards identifying openings for more inclusive and accommodating regimes before civil war breaks out (Chenoweth \& Stephan, 2011; Cunningham, 2013b). This task is all the more urgent because fighting civil wars itself increases the risk of violent demonstration effects (Bormann \& Hammond, 2016). Governments engaged in an ongoing rebellion thus face a Catch-22 when deciding whether to continue confronting or to concede to one challenger. Granting concessions may still present the lesser of two evils. 


\section{References}

Achen, Christopher H (2005) Let's put garbage-can regressions and garbage-can probits where they belong. Conflict Management and Peace Science 22(4): 327-339.

Bates, Robert H (1974) Ethnic competition and modernization in contemporary africa. Comparative Political Studies 6(4): 457-484.

Boix, Carles \& Milan W Svolik (2013) The foundations of limited authoritarian government: Institutions and power-sharing in dictatorships. Journal of Politics 75(2): $300-316$.

Bormann, Nils-Christian \& Jesse Hammond (2016) A slippery slope - The domestic diffusion of ethnic civil war. International Studies Quarterly 60(4): 587-598.

Brass, Paul R (1991) Ethnicity and Nationalism. Princeton, NJ: Sage Publications.

Bueno de Mesquita, Bruce; Alastair Smith, Randolph M Siverson \& James D Morrow (2003) The Logic of Political Survival. Boston: The MIT Press.

Buhaug, Halvard (2006) Relative capability and rebel objective in civil war. Journal of Peace Research 43(6): 691-708.

Bunce, Valerie (1999) Subversive Institutions: The Design and the Destruction of Socialism and the State. Cambridge, UK: Cambridge University Press.

Carter, David B \& Curtis S Signorino (2010) Back to the future: Modeling time dependence in binary data. Political Analysis 18(3): 271-292.

Cederman, Lars-Erik; Simon Hug, Andreas Schädel \& Julian Wucherpfennig (2015) Territorial autonomy in the shadow of conflict: Too little, too late? American Political Science Review 109(2): 354-370.

Cederman, Lars-Erik; Andreas Wimmer \& Brian Min (2010) Why do ethnic groups rebel? New data and analysis. World Politics 62(1): 87-119.

Cheibub, José A \& Jude C Hays (2017) Elections and civil war in Africa. Political Science Research and Methods 5(1): 81-102.

Chenoweth, Erica \& Maria J Stephan (2011) Why Civil Resistance Works: The Strategic Logic of Nonviolent Conflict. New York, NY: Columbia University Press.

Coggins, Bridget (2011) Friends in high places: International politics and the emergence of states from secessionism. International Organization 65(3): 433-467.

Cunningham, David E; Kristian S Gleditsch \& Idean Salehyan (2009) It takes two: A dyadic analysis of civil war duration and outcome. Journal of Conflict Resolution 53(4): 570-597.

Cunningham, Kathleen Gallagher (2011) Divide and conquer or divide and concede: How do states respond to internally divided separatists? American Political Science Review 105(2): $275-297$. 
Cunningham, Kathleen Gallagher (2013a) Actor fragmentation and civil war bargaining: How internal divisions generate civil conflict. American Journal of Political Science 57(3): 659-672.

Cunningham, Kathleen Gallagher (2013b) Understanding strategic choice: The determinants of civil war and nonviolent campaign in self-determination disputes. Journal of Peace Research 50(3): 291-304.

Evans, Peter B (1989) Predatory, developmental, and other apparatuses: A comparative political economy perspective on the third world state. Sociological Forum 4(4): 561587.

Forsberg, Erika (2013) Ethnic dominoes: Evaluating domino effects of granting territorial concessions to separatist groups. International Studies Quarterly 57(2): 329-340.

Gleditsch, Nils Petter; Peter Wallensteen, Mikael Eriksson, Margareta Sollenberg \& Havard Strand (2002) Armed conflict 1946-2001: A new dataset. Journal of Peace Research 39(5): 615-637.

Griffiths, Ryan D (2015) Between dissolution and blood: How administrative lines and categories shape secessionist outcomes. International Organization 69(3): 731-751.

Grigoryan, Arman (2012) Ethnofederalism, separatism, and conflict: What we have learned from the Soviet and Yugoslav experiences. International Political Science Review 33(5): 520-538.

Gurr, Ted R (2000) Peoples versus States: Minorities At Risk in the New Century. Washington, DC: United States Institute of Peace Press.

Hale, Henry E (2000) The parade of sovereignties: Testing theories of secession in the Soviet setting. British Journal of Political Science 30(1): 31-56.

Hartzell, Caroline \& Matthew Hoddie (2007) Crafting Peace: Power-Sharing Institutions and the Negotiated Settlement of Civil Wars. University Park, PA: Pennsylvania State University Press.

Hegre, Håvard \& Nicholas Sambanis (2006) Sensitivity analysis of empirical results on civil war onset. Journal of Conflict Resolution 50(4): 508-535.

Hug, Simon (2013) The use and misuse of the "Minorities at Risk" project. Annual Review of Political Science 16: 191-208.

Hunziker, Philipp \& Nils-Christian Bormann. (2013) Size and wealth in the international system: Population and GDP per capita data for political science. Typescript: ETH Zurich: 1-22.

Jarstad, Anna K \& Desirée Nilsson (2008) From words to deeds: The implementation of power-sharing pacts in peace accords. Conflict Management and Peace Science 25(3): 206-223.

Kalyvas, Stathis N \& Laia Balcells (2010) International system and technologies of rebellion: How the end of the Cold War shaped internal conflict. American Political Science Review 104(3): 415-429. 
Kalyvas, Stathis N \& Matthew A Kocher (2007) How "free" is free riding in civil wars?: Violence, insurgency, and the collective action problem. World Politics 59(2): 177-216.

Kreutz, Joakim (2010) How and when armed conflicts end: Introducing the UCDP Conflict Termination Dataset. Journal of Peace Research 47(2): 243-250.

Lacina, Bethany (2014) How governments shape the risk of civil violence: India's federal reorganization, 1950-56. American Journal of Political Science 58(3): 720-738.

Lemarchand, Rene (1972) Political clientelism and ethnicity in tropical africa: Competing solidarities in nation-building. American Political Science Review 66(1): 68-90.

Lijphart, Arend (1977) Democracy in Plural Societies: A Comparative Exploration. New Haven, CT: Yale University Press.

Mattes, Michaela \& Burcu Savun (2009) Fostering peace after civil war: Commitment problems and agreement design. International Studies Quarterly 53(3): 737-759.

Mukherjee, Bumba (2006) Why political power-sharing agreements lead to enduring peaceful resolution of some civil wars, but not others? International Studies Quarterly 50(2): 479-504.

Nilsson, Desirée (2008) Partial peace: Rebel groups inside and outside of civil war settlements. Journal of Peace Research 45(4): 479-495.

Nilsson, Desirée (2010) Turning weakness into strength. Conflict Management and Peace Science 27(3): 253-271.

Roeder, Philip G (1991) Soviet federalism and ethnic mobilization. World Politics 43(2): 196-232.

Roessler, Philip G (2011) The enemy from within. personal rule, coups, and civil wars in Africa. World Politics 63(2): 300-346.

Sambanis, Nicholas; Micha Germann \& Andreas Schädel (2018) SDM: A new data set on self-determination movements with an application to the reputational theory of conflict. Journal of Conflict Resolution 62(3): 656-686.

Themnér, Lotta \& Peter Wallensteen (2014) Armed conflicts, 1946-2013. Journal of Peace Research 51(4): 541-554.

Toft, Monica Duffy (2002) Indivisible territory, geographic concentration, and ethnic war. Security Studies 12(2): 82-119.

Toft, Monica Duffy (2003) The Geography of Ethnic Violence: Identity, Interests, and the Indivisibility of Territory. Princeton, NJ: Princeton University Press.

Tull, Denis M \& Andreas Mehler (2005) The hidden costs of power-sharing: Reproducing insurgent violence in Africa. African Affairs 104(416): 375-398.

Vogt, Manuel; Nils-Christian Bormann, Seraina Ruegger, Lars-Erik Cederman, Philipp Hunziker \& Luc Girardin (2015) Integrating data on ethnicity, geography, and conflict: The Ethnic Power Relations dataset family. Journal of Conflict Resolution 59(7): $1327-1342$. 
Walter, Barbara F (2006a) Building reputation: Why governments fight some separatists but not others. American Journal of Political Science 50(2): 313-330.

Walter, Barbara F (2006b) Information, uncertainty, and the decision to secede. International Organization 60(1): 105-135.

Walter, Barbara F (2009a) Bargaining failures and civil war. Annual Review of Political Science 12: 243-261.

Walter, Barbara F (2009b) Reputation and Civil War: Why Separatist Conflicts Are So Violent. New York, NY: Cambridge University Press.

Wilkinson, Steven I (2000) India, consociational theory, and ethnic violence. Asian Survey 40(5): $767-791$.

Wucherpfennig, Julian; Nils Metternich, Lars-Erik Cederman \& Kristian S Gleditsch (2012) Ethnicity, the state and the duration of civil war. World Politics 64(1): 79115.

\section{Biographical statement}

NILS-CHRISTIAN BORMANN, b. 1985, PhD (ETH Zürich, 2014); Lecturer, University of Exeter (2015-) \& Visiting Professor of International Political Studies, University of Witten-Herdecke (2017-2018).

BURCU SAVUN, b. 1976, PhD (Rice University, 2006); Associate Professor of Political Science, University of Pittsburgh (2006-). 